\title{
Reduction of Serum Insulin-like Growth Factor-I by Dietary Protein Restriction Is Age Dependent
}

\author{
THERESE FLIESEN, DOMINIQUE MAITER, GUY GERARD, LOUIS E. UNDERWOOD, \\ MARC MAES, AND JEAN-MARIE KETELSLEGERS \\ Unité de Diabétologie et Nutrition [T.F., D.M., M.M., J.M.K.] and Unité de Biométrie et Analyse des Données \\ [G.G.], University of Louvain, Brussels, Belgium; Department of Pediatrics, Division of Pediatric Endocrinology \\ [L.E.U.], University of North Carolina, Chapel Hill, North Carolina 27599
}

\begin{abstract}
We have determined if dietary protein restriction for 1 wk has differential effects on growth, serum IGF-I, and liver growth hormone receptors at various stages of development. Female Wistar rats were fed a low (5\%) protein diet for $7 \mathrm{~d}$ at $3,4,6,8$, and 12 wk of age, whereas controls were maintained on a normal $(15 \%)$ protein diet. Body wt gain was impaired in the groups fed the low protein diet, despite normal energy intake, and the effect was attenuated with age. Liver cell number (DNA content) was reduced by low protein feeding in the 3-, 4-, and 6 -wk age groups $(p<0.01)$, but not in the older animals. Protein restriction caused a dramatic decrease in serum IGF-I in the younger animals $(90$ and $82 \%$ reduction versus normal fed age-matched controls, at 3 and $4 \mathrm{wk}$, respectively; $p<0.001$ ), and this effect was progressively attenuated with increasing age $(49,40$, and $25 \%$ reductions of serum IGF-I at 6,8 , and $12 \mathrm{wk}$, respectively). Changes in serum IGF-I correlated with those of liver cell number $(r=0.80 ; p<0.001)$. Total and free liver growth hormone receptors were slightly decreased in the low protein diet groups at $4(p<0.05)$ and $6 \mathrm{wk}$ (total: $p<0.001$; free: $p$ $<0.01$ ) but not in the other age groups. The occurrence of profound diet induced reductions in IGF-I without proportional reductions in liver $G H$ receptors suggest that the apparent GH resistance occurs at a postreceptor level. Because the degree of IGF-I reduction correlates with the severity of retardation of liver growth during dietary protein restriction at different ages, we conclude that the effect of protein restriction on liver growth could be mediated through IGF-I. (Pediatr Res 26: 415-419, 1989)
\end{abstract}

Abbreviations

rGH, rat growth hormone

bGH, bovine growth hormone

ANOVA, analysis of variance

The GH-dependent peptide IGF-I is widely believed to be one of the principal stimulators of the cell proliferation that results in somatic growth (1). Regulated by food intake and nutritional

Received February 21, 1989; accepted June 20, 1989.

Correspondence L. E. Underwood, M.D., CB \#7220, The University of North Carolina at Chapel Hill, Clinical Sciences Building 229 H, Chapel Hill, NC 27599.

Reprint requests Dr. J. M. Ketelslegers, Unité de Diabétologie et Nutrition, UCL-DIAB/54.74, Avenue Hippocrate 54, 1200 Bruxelles, Belgium.

Supported by Grants from the Fonds de la Recherche Scientifique Médicale (3.4538.80) and the Fonds National de la Recherche Scientifique (1.5.333.86F) Brussels, Belgium, and by NIH Research Grants AM-01022 and HD-08299. D.M. is Research Assistant of the National Fund for Scientific Research, Brussels, Belgium. status $(2,3)$, serum concentrations of IGF-I are reduced by restriction of energy or protein (4-6). These reductions in IGFI, which occur despite adequate serum GH concentrations, may be due to decreased liver GH receptors or postreceptor defects in $\mathrm{GH}$ action $(4,7)$. The adverse effects of nutrient deprivation on growth are greatest in young animals, in whom growth depends heavily on cell proliferation $(8,9)$. The study reported here was undertaken to determine whether dietary protein restriction in rats at various times between weaning and postpuberty (3-12 wk of age) has differential effects on serum IGF-I concentrations. Specifically, we hypothesized that young animals, in whom malnutrition impairs growth most severely, would experience the greatest reductions in serum IGF-I. To determine the mechanisms that might regulate IGF-I in such animals, we also have determined serum concentrations of $\mathrm{GH}$ and insulin, as well as liver $\mathrm{GH}$ binding.

\section{MATERIALS AND METHODS}

Animals and experimental design. Female Wistar rats were housed individually in metabolic cages under controlled conditions (light from $0600-1800 \mathrm{~h}$; constant temperature, $22^{\circ} \mathrm{C}$ ) and fed a normal protein powdered diet $(15 \%$ casein; $325 \mathrm{cal} / 100 \mathrm{~g})$. At the ages of $3,4,6,8$ and 12 weeks, 6 rats in each age-group (12 rats/group) were maintained on the normal protein diet for 1 additional wk, and six rats were fed a low protein isocaloric diet ( $5 \%$ casein; $325 \mathrm{cal} / 100 \mathrm{~g}$ ) for the same period. Body wt and food intake were recorded daily, and after $7 \mathrm{~d}$ the animals were killed by decapitation between 0930 and $1100 \mathrm{~h}$. Blood was collected from the trunk vessels and kept at $4^{\circ} \mathrm{C}$ for up to 60 min. After centrifugation, the serum was stored at $-20^{\circ} \mathrm{C}$ until assayed for IGF-I, rGH, insulin, and glucose. At death, each liver was removed promptly, weighed, homogenized as previously described (10), and stored at $-20^{\circ} \mathrm{C}$ until assayed for $\mathrm{bGH}$ binding, protein, and DNA content.

$R I A$ and binding studies. IGF-I was measured by RIA on unextracted serum using a nonequilibrium technique $(11,12)$. A pool of sera from 10 adult male rats was used as the standard; its potency was designated as $1 \mathrm{U} / \mathrm{mL}$. To insure that differences in the IGF-I measured between experimental groups were not due to interference of IGF-I binding proteins in the RIA, IGF-I was also assayed after extraction on pools of equal volumes of serum samples from each experimental group $(n=16)$. These pools of sera were acidified and extracted using ODC-silica columns (C18 Sep-Pak; Waters Associates, Milford, MA), sequentially eluting binding proteins with $7 \%$ acetic acid and IGFI with $100 \%$ methanol $(13,14)$. With this technique, $>99 \%$ of binding proteins are removed and $68 \%$ of IGF-I present in serum is recovered. In assays of extracted serum, pure plasma-derived IGF-I (PS III) was used as standard and corrections are made for losses during extraction. Serum rGH was measured (14) using 
the reagents prepared by Dr. A. F. Parlow (UCLA, Harbor Campus, Torrence, CA) and obtained through the NIDDK Rat Pituitary Program (National Institute of Diabetes, Digestive Diseases and Kidney, National Institutes of Health, Bethesda, MD). Serum insulin concentrations were determined by RIA as reported previously (15), except that the second antibody was a solid-phase coupled antiguinea pig $\gamma$-globulin (IRE, Fleurus, Belgium). Glucose was measured in serum by an automated glucose-oxidase method (Beckman Instruments, Fullerton, CA).

Somatogenic binding sites were determined on liver homogenates using ${ }^{125} \mathrm{I}-\mathrm{bGH}(10)$. The highly purified bGH used for iodination was generously provided by Dr. A. C. Paladini (Buenos-Aires, Argentina). Bovine GH (USDA B-1) was used as unlabeled hormone for the determination of nonspecific binding. Specific binding of bGH was measured by determining the difference between the radioactivity bound in the absence and in the presence of unlabelled hormone ( $1 \mu \mathrm{g} / \mathrm{tube})$. To measure total bGH binding, liver homogenates were treated for $10 \mathrm{~min}$ with $4 \mathrm{M} \mathrm{MgCl}_{2}$ at room temperature to remove endogenous ligand $(10,16)$. Tracer binding determined after $\mathrm{MgCl}_{2}$ treatment were corrected for protein loss $\left(22.4 \pm 5.8 \%\right.$ versus $\mathrm{H}_{2} \mathrm{O}$-treated homogenates; mean $\pm \mathrm{SD}$ ). Free receptors were assessed simultaneously on water-treated homogenates. Proteins were determined by the method of Lowry et al. (17), and DNA was measured by fluorometry, as described by Karsten and Wollenberger (18).

Statistical analysis. Data were analyzed by two-way ANOVA using the Statistical Analysis System (19) to determine the respective influences of the two main factors (protein content of the diet and age of the rats) and their interactions on the different variables studied. The variables are shown as mean \pm SEM. When the diet effect was significant, or when interaction between the two factors was significant $(p<0.05)$ for one variable differences between means were analyzed by $t$ tests using the pooled residual mean square of the ANOVA, to determine the specific effect of diet at each age separately.

\section{RESULTS}

Body wt gain was impaired during protein restriction in the 3 to $8 \mathrm{wk}$ age groups $(p<0.001)$ but not in the $12 \mathrm{wk}$ age group $(p>0.05)$ (Table 1). The effect was age-dependent (age $\times$ diet interaction in ANOVA for body weight gain: $p<0.001$ ), being

Table 1. Food intake, body wt gain, and tail length in rats fed normal and low protein diet (mean \pm SEM)

\begin{tabular}{ccccc}
\hline $\begin{array}{c}\text { Age group } \\
(\text { wk })^{*}\end{array}$ & $\begin{array}{c}\text { Diet } \\
\text { (\% protein) }\end{array}$ & $\begin{array}{c}\text { Food intake } \\
(\mathrm{g} / \mathrm{d})\end{array}$ & $\begin{array}{c}\text { Body wt } \\
\text { gain }(\mathrm{g}) \dagger\end{array}$ & $\begin{array}{c}\text { Tail length at } \\
\text { sacrifice }(\mathrm{cm})\end{array}$ \\
\hline 3 & 15 & $10.4 \pm 0.3$ & $28.6 \pm 1.1$ & $9.5 \pm 0.3$ \\
& 5 & $9.6 \pm 0.5$ & $7.3 \pm 0.7 \ddagger$ & $8.9 \pm 0.2$ \\
4 & 15 & $12.0 \pm 0.6$ & $33.8 \pm 1.2$ & $10.5 \pm 0.3$ \\
& 5 & $11.6 \pm 0.3$ & $10.1 \pm 1.3 \ddagger$ & $9.8 \pm 0.4 \S$ \\
6 & 15 & $15.9 \pm 0.2$ & $20.6 \pm 1.4$ & $14.4 \pm 0.4$ \\
& 5 & $16.7 \pm 0.7$ & $3.7 \pm 1.6 \ddagger$ & $13.4 \pm 0.4 \|$ \\
& & & & \\
& 15 & $15.3 \pm 0.7$ & $18.7 \pm 2.0$ & $15.6 \pm 0.3$ \\
& 5 & $16.6 \pm 0.8$ & $8.4 \pm 2.1 \ddagger$ & $16.0 \pm 0.3$ \\
& & & & \\
& 15 & $17.3 \pm 0.8$ & $8.4 \pm 1.4$ & $17.6 \pm 0.3$ \\
& 5 & $17.7 \pm 0.5$ & $5.6 \pm 1.3$ & $17.6 \pm 0.3$ \\
\hline
\end{tabular}

* Age at which the 1-wk experimental period is begun.

$\dagger$ Body wt gain over the 1 -wk experimental period.

$\ddagger p<0.001$ versus $15 \%$ protein diet.

$\S p<0.05$ versus $15 \%$ protein diet.

$\| p<0.01$ versus $15 \%$ protein diet. progressively less pronounced as the animals increased in age. Similarly, a slight but significant effect of protein restriction on growth of the tail was observed in the 4- and 6-wk age groups. DNA content per liver, an index of cell number, was reduced significantly by the protein restriction in the 3-, 4-, and 6-wk groups $(35,28$, and $20 \%$, respectively; $p<0.01)$, but not in the 8 - and 12-wk groups. Liver protein content and cell size (protein/ DNA ratio) were lower in each of the malnourished groups, regardless of age (Table 2).

Before puberty ( 3 and $4 \mathrm{wk}$ ) the serum IGF-I concentration was profoundly reduced by protein restriction, being 0.5 and 0.6 $\mathrm{U} / \mathrm{mL}$ in control rats and 0.05 and $0.1 \mathrm{U} / \mathrm{mL}$ in the $5 \%$ proteinfed rats, respectively (90 and $83 \%$ decrease in comparison to the age-matched controls; $p<0.001$; Fig. 1). At later stages of development, IGF-I was reduced less dramatically by protein deprivation. Thus at 6,8 , and $12 \mathrm{wk}$ of age, IGF-I was reduced by $49 \%(p<0.001), 40 \%(p<0.001)$, and $25 \%(p<0.05)$ in comparison to the age-matched controls (Fig. 1). This age dependency of diet-induced reductions in IGF-I was highly significant (age $\times$ diet interaction in ANOVA for IGF-I: $p<0.001$ ).

The percent decrease of serum IGF-I after protein restriction was slightly less in all age groups when assayed after extraction than when determined in unextracted samples (Table 3). However, the age effect of the IGF-I reduction induced by the low protein diet remained evident after sample extraction, because the IGF-I decrease was $69 \%$ at 4 wk and only $17 \%$ at $12 \mathrm{wk}$. Diet-induced changes of IGF-I measured on unextracted sera correlated significantly with liver DNA content $(r=0.80 ; p<$ 0.001 ; Fig. 2), but not with protein/DNA ratios $(r=0.24 ; p>$ $0.05)$.

The low protein diet did not change serum $\mathrm{GH}$ concentrations but caused a significant mean $43 \%$ decrease in serum insulin, which was not age-dependent (overall diet effect in ANOVA: $p$ $<0.001$; comparison of differences between means: $p<0.05$ at wk 4, 8, and 12). Serum glucose did not change with age or diet (Table 4).

Compared to controls, $7 \mathrm{~d}$ of protein restriction caused total ( $\mathrm{MgCl}_{2}$-treated homogenates) liver $\mathrm{GH}$ binding sites to be reduced by $38 \%(p<0.05)$ and $45 \%(p<0.001)$ in the $4-$ and $6-$ wk age groups, respectively (Fig. 3). No change was observed in the 3-wk or in the 8 - and 12-wk age groups. Total liver GH binding sites increased with age in control animals, the most significant rise occurring at the onset of puberty (between 4 and $6 \mathrm{wk}$ of age). The changes in free $\left(\mathrm{H}_{2} \mathrm{O}\right.$-treated homogenates) liver binding sites paralleled those of total $\mathrm{GH}$ receptors.

\section{DISCUSSION}

Our study shows that the serum IGF-I concentrations are critically dependent on dietary protein supply at the early stages of development, and that this protein dependence decreases with age. One wk of protein deprivation reduced IGF-I concentrations in prepubertal rats by $90 \%$, the values being as low as those found in hypophysectomized animals. This response to the nutritional insult became progressively less pronounced with increasing age, so that protein deprivation in postpubertal rats caused only a $25 \%$ reduction in IGF-I. The changes in IGF-I observed are attributable primarily to the dietary protein deprivation, because the energy intakes of protein-restricted rats were equivalent to controls. Our observations agree with the results of Prewitt et al. (6), which show that serum IGF-I in postweanling rats is influenced by dietary protein and that reduction of IGF-I has a linear relationship to the degree of protein restriction. The results obtained are not due to nonspecific interference by IGF binding proteins in the RIA on unextracted serum, because similar changes were also observed when IGF-I was determined after separation from the binding proteins. The results, however, do not exclude the possibility that the changes in IGF-I observed 
Table 2. Liver wt, DNA, and protein contents, and protein DNA/ratios in rats fed normal and low protein diets (mean \pm SEM)

\begin{tabular}{cccccc}
\hline $\begin{array}{c}\text { Age groups } \\
(\text { wk) }\end{array}$ & $\begin{array}{c}\text { Diet } \\
\text { (\% protein) }\end{array}$ & $\begin{array}{c}\text { Liver wt } \\
(\mathrm{g})\end{array}$ & $\begin{array}{c}\text { DNA } \\
(\mathrm{mg} / \mathrm{liver})\end{array}$ & $\begin{array}{c}\text { Protein } \\
(\mathrm{mg} / \mathrm{liver})\end{array}$ & $\begin{array}{c}\text { Protein } \\
\text { DNA }\end{array}$ \\
\hline 3 & 15 & $3.1 \pm 0.2$ & $12.0 \pm 0.6$ & $485 \pm 22$ & $41 \pm 1$ \\
& 5 & $1.9 \pm 0.1 \dagger$ & $7.8 \pm 0.6 \ddagger$ & $238 \pm 13 \dagger$ & $31 \pm 2 \ddagger$ \\
4 & 15 & $3.5 \pm 0.1$ & $13.8 \pm 1.2$ & $547 \pm 27$ & $41 \pm 3$ \\
& 5 & $2.6 \pm 0.2 \ddagger$ & $10.0 \pm 0.9 \ddagger$ & $320 \pm 18 \dagger$ & $33 \pm 2 \S$ \\
6 & 15 & $5.5 \pm 0.2$ & $19.3 \pm 0.3$ & $848 \pm 56$ & $44 \pm 4$ \\
& 5 & $5.1 \pm 0.3$ & $15.5 \pm 0.7 \ddagger$ & $664 \pm 27 \ddagger$ & $43 \pm 1$ \\
& 15 & $6.3 \pm 0.4$ & $21.3 \pm 0.7$ & $1015 \pm 63$ & $48 \pm 3$ \\
& 5 & $6.2 \pm 0.4$ & $22.3 \pm 0.8$ & $860 \pm 72 \S$ & $40 \pm 3 \S$ \\
& 15 & $6.7 \pm 0.1$ & $22.7 \pm 0.8$ & $1099 \pm 40$ & $49 \pm 3$ \\
& 5 & $6.7 \pm 0.3$ & $23.3 \pm 1.4$ & $920 \pm 46 \ddagger$ & $40 \pm 2 \S$ \\
\hline
\end{tabular}

* Age at which the 1-wk experimental period is begun.

$\dagger p<0.001$ versus $15 \%$ protein.

$\ddagger p<0.01$ versus $15 \%$ protein.

$\S p<0.05$ versus $15 \%$ protein.

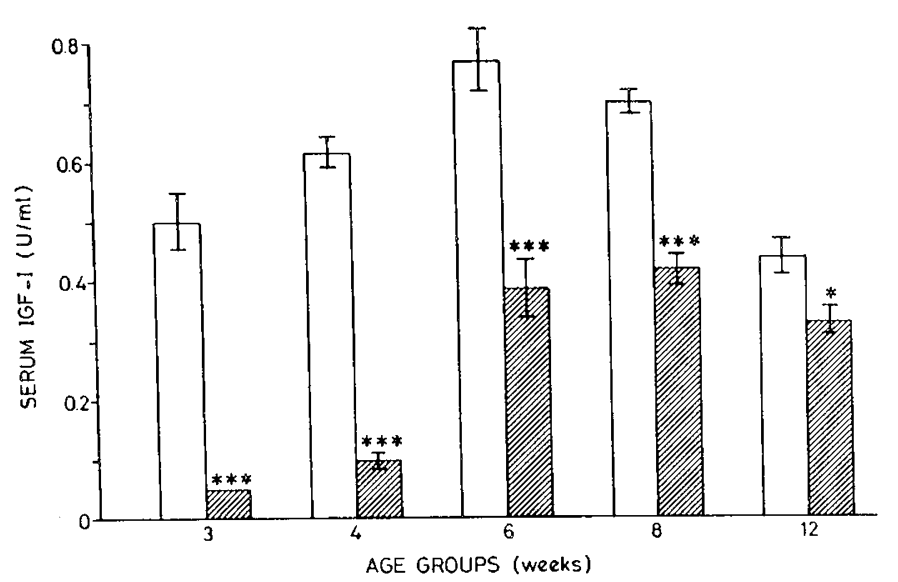

Fig. 1. Effect of 1-wk dietary protein restriction upon serum IGF-I at different ages. The groups fed the low and normal protein diets are represented by the hatched and open bars respectively. The various age groups are as represented. Data are mean \pm SE. *, ${ }^{* * *}: p<0.05$ and $<$ 0.001 versus normal fed controls of the same age.

Table 3. Serum IGF-I after extraction in rats fed normal and low protein diet

\begin{tabular}{|c|c|c|c|}
\hline \multirow{3}{*}{$\begin{array}{l}\text { Age group } \\
(w k)^{*}\end{array}$} & \multirow{3}{*}{$\begin{array}{c}\text { Diet } \\
\text { (\% protein) }\end{array}$} & \multicolumn{2}{|c|}{ IGF-I (extracted) $\dagger$} \\
\hline & & \multicolumn{2}{|c|}{$5 \%$ vs $15 \%$ protein diet } \\
\hline & & $(\mathrm{nmol} / \mathrm{L})$ & (\% decrease $)$ \\
\hline 3 & $\begin{array}{r}15 \\
5\end{array}$ & 136 & 66 \\
\hline 4 & $\begin{array}{r}15 \\
5\end{array}$ & $\begin{array}{r}169 \\
53\end{array}$ & 69 \\
\hline 6 & $\begin{array}{r}15 \\
5\end{array}$ & $\begin{array}{l}244 \\
173\end{array}$ & 29 \\
\hline 8 & $\begin{array}{r}15 \\
5\end{array}$ & $\begin{array}{l}286 \\
226\end{array}$ & 21 \\
\hline 12 & $\begin{array}{r}15 \\
5\end{array}$ & $\begin{array}{l}230 \\
190\end{array}$ & 17 \\
\hline
\end{tabular}

* Age at which the experimental period is begun.

$\uparrow$ Equal volumes of serum from each experimental group were pooled, extracted and assayed for IGF-I as described in "Materials and Methods." $\$ 15 \%$ protein $-5 \%$ protein $/ 15 \%$ protein $\times 100$.

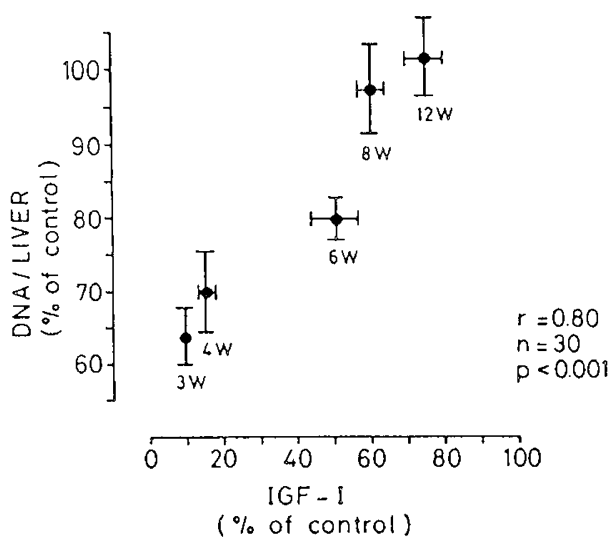

Fig. 2. Comparison of the effects of 1-wk dietary protein restriction upon serum IGF-I (unextracted) and liver DNA content at various ages. The IGF-I and DNA/liver in the protein restricted rats of each age group are expressed as a percentage of the values determined in the normal fed controls of the same age (percent of controls). The data are represented as means of each age group $\pm \mathrm{SE}$.

Table 4. Serum glucose, insulin, and growth hormone in rats fed the normal and low protein diet

\begin{tabular}{ccccc}
\hline $\begin{array}{c}\text { Age groups } \\
\text { (wk)* }\end{array}$ & $\begin{array}{c}\text { Diet } \\
\text { (\% protein) }\end{array}$ & $\begin{array}{c}\text { Serum glucose } \\
(\mathrm{mmol} / \mathrm{L})\end{array}$ & $\begin{array}{c}\text { Serum insulin } \\
(\mathrm{pmol} / \mathrm{L}) \dagger\end{array}$ & $\begin{array}{c}\text { Serum growth } \\
\text { hormone } \\
(\mathrm{ng} / \mathrm{mL}) \ddagger\end{array}$ \\
\hline \multirow{2}{*}{3} & 15 & $7.8 \pm 0.2$ & $145 \pm 14$ & $8(5-129)$ \\
& 5 & $8.1 \pm 0.6$ & $53 \pm 3$ & $12(<5-39)$ \\
4 & 15 & $8.1 \pm 0.3$ & $205 \pm 51$ & $11(8-16)$ \\
6 & 5 & $7.7 \pm 0.3$ & $79 \pm 15 \S$ & $7(<5-25)$ \\
& 15 & $7.9 \pm 0.3$ & $267 \pm 55$ & $17(6-212)$ \\
& 5 & $7.7 \pm 0.2$ & $210 \pm 70$ & $9(<5-17)$ \\
8 & 15 & $7.9 \pm 0.3$ & $424 \pm 56$ & $48(15-213)$ \\
& 5 & $7.9 \pm 0.3$ & $284 \pm 22 \S$ & $28(9-131)$ \\
12 & 15 & $7.4 \pm 0.4$ & $374 \pm 44$ & $68(17-273)$ \\
& 5 & $7.3 \pm 0.2$ & $236 \pm 36 \S$ & $76(23-149)$ \\
\hline
\end{tabular}

* Age at which the 1-wk experimental period is begun.

$\dagger$ Determined at time of death; mean $\pm \mathrm{SE}$.

$\ddagger$ Determined at time of sacrifice; median with range; results are expressed as $\mathrm{ng} / \mathrm{mL}$ of the $\mathrm{rGH}-\mathrm{RP}-1$ reference preparation.

$\S p<0.05$ versus $15 \%$ protein.

(whether measured on extracted or unextracted samples) are secondary to changes in concentration of IGF binding proteins.

The high degree of sensitivity of the immature rat to protein deprivation was not due to a selective loss of liver GH receptors. 


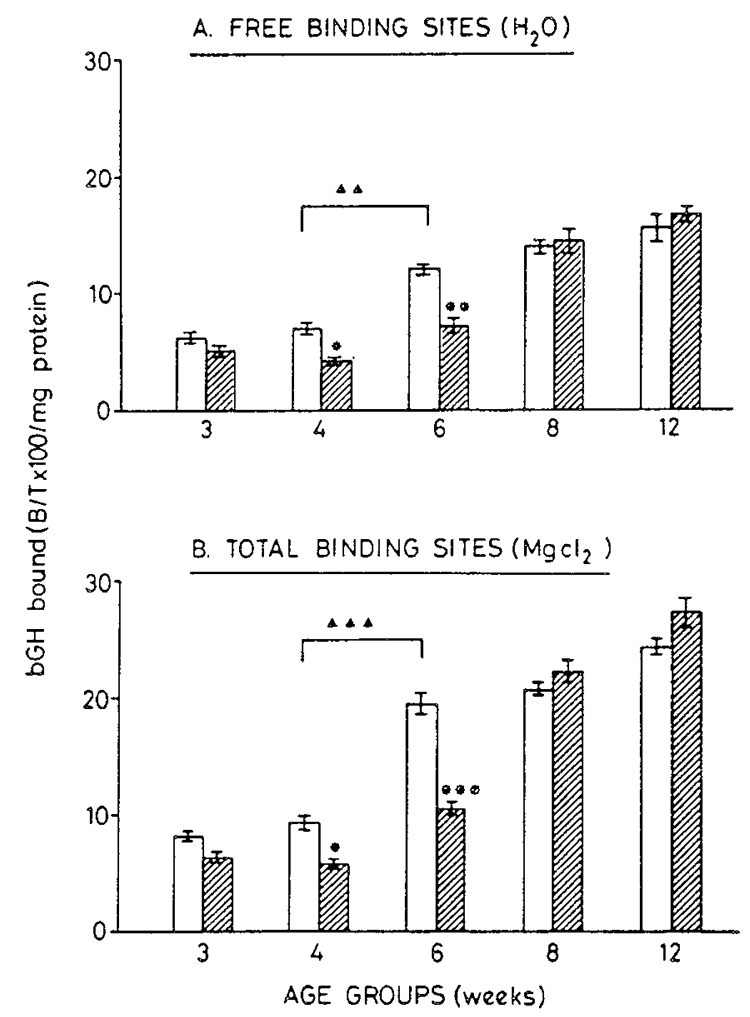

Fig. 3. Effect of 1-wk dietary protein restriction upon liver GH receptors at different ages. The groups fed the low and normal protein diets are represented by the hatched and open bars, respectively. The free and total binding sites are determined as described in "Materials and Methods." The specifically bound bGH $(B)$ is expressed as a percentage of total $(T)$ labeled bGH incubated with the liver homogenates. The various age groups are represented. Data are mean \pm S.E. ${ }^{*},{ }^{* *},{ }^{* * *}: p<0.05,<$ $0.01,<0.001$ versus normal fed controls of the same age. $\mathbf{\Lambda} \mathbf{\Lambda}, \mathbf{\Lambda} \mathbf{\Delta} \mathbf{\Lambda}: p$ $<0.01,<0.001 ; 4-$ versus 6 -wk age groups.

Indeed, the pronounced decrease in IGF-I observed prepubertally occurred without significant (3wk) or with minimal (4 wk) changes of such receptors. Furthermore, we still observed significant reductions in IGF-I with protein restriction at later stages of development ( 8 and $12 \mathrm{wk}$ ) without any change in total or free $\mathrm{GH}$ binding. These observations tend to support our earlier studies $(7,20)$ showing that a postreceptor defect(s) plays a predominant role in the induction of GH resistance in dietary protein restriction. In the pregnant rat, dietary protein restriction may have different consequences. Indeed, Pilistine et al. (21) showed that in that situation, human GH infusion prevented the serum IGF-I fall but not the body wt loss caused by protein depletion.

Although insulin participates to the maintenance of serum IGF-I concentrations (2) and the protein-restricted animals were hypoinsulinemic, reduced insulin probably does not by itself explain the reduction in IGF-I concentrations. We reach this conclusion because the hypoinsulinemia was not age dependent as were the reductions of IGF-I concentrations. Furthermore, we have shown that protein restriction reduced IGF-I independent of insulin (14).

Before weaning, malnutrition retards cell multiplication (reduction in DNA content per organ), resulting in a permanent stunting of body and organ mass even after prolonged rehabilitation $(9,22-24)$. In contrast, the predominant effect of malnutrition during early adulthood is to reduce cell size. This allows catch-up growth after refeeding. In this study, we confirm the age dependence of the effects of malnutrition upon liver cell number, and show that this cell deficit correlates with decreased serum IGF-I. The decrease in hepatic mass may contribute to the reduction in plasma IGF-I. At the earlier stages of development, however, $26-39 \%$ decrease in liver wt, or $28-35 \%$ reduction in liver DNA content (an index of cell number) cannot account for the $83-90 \%$ reduction in IGF-I. This suggests that the IGF-I production per cell is reduced. It is possible therefore that the profound reduction in IGF-I caused by protein malnutrition in early development could play a role in the reduced cell number. Although low concentrations of IGF-I in serum may not have caused attenuation of the increase in liver cell number directly, it is most likely that serum concentrations of this growth factor reflect tissue concentrations (25). Because the IGF-I in tissues may act by autocrine or paracrine mechanisms (26), decreased hepatic IGF-I could be a means whereby liver growth is attenuated. Similarly, decreased IGF-I in other tissues during protein deprivation could serve as the mechanism for generalized growth retardation.

Acknowledgments. The authors thank Professor A. E. Lambert and Professor P. Malvaux for continuous support. The expert technical assistance of E. Adam and E. Bruton, and the excellent secretarial work of $M$. Detaille and N. Amat are gratefully acknowledged.

\section{REFERENCES}

1. Van Wyk JJ, Underwood LE 1978 The somatomedins and their actions. In: Gerald Litwack (ed) Biochemical Actions of Hormones, Vol V. Academic Press, New York, pp 101-148

2. Phillips LS, Unterman TG 1984 Somatomedin activity in disorders of nutrition and metabolism. Clin Endocrinol Metab 13:145-189

3. Underwood LE, Clemmons DR, Maes M, D’Ercole AJ, Ketelslegers JM 1986 Regulation of somatomedin-C/insulin-like growth factor I by nutrients. Hormone Res 24:166-176

4. Maes M, Underwood LE, Ketelslegers JM 1983 Plasma somatomedin-C in fasted and refed rats: close relationship with changes in liver somatogenic but not lactogenic binding sites. J Endocrinol 97:243-252

5. Isley WL, Underwood LE, Clemmons DR 1983 Dietary components that regulate serum somatomedin-C concentrations in humans. J Clin Invest 71:175-182

6. Prewitt TE, D'Ercole AJ, Switzer BR, Van Wyk JJ 1982 Relationship of serum immunoreactive somatomedin-C to dietary protein and energy in growing rats. J Nutr 1 12:144-150

7. Maiter D, Maes M, Underwood LE, Fleisen T, Gerard G, Ketelslegers JM 1988 Early changes in serum concentrations of somatomedin-C induced by dietary protein deprivation in rats: contributions of growth hormone receptor and post-receptor defects. J Endocr 118:113-120

8. Winick M, Noble A 1965 Quantitative changes in DNA, RNA, and protein during prenatal and postnatal growth in the rat. Dev Biol 12:451-466

9. Widdowson EM, McCance RA 1963 The effect of finite periods of undernutrition at different ages on the composition and subsequent development of the rat. Proc Roy Soc Lond 158B:329-342

10. Maiter D, Underwood LE, Maes M, Ketelslegers JM 1988 Acute downregulation of the somatogenic receptors in rat liver by a single injection of growth hormone. Endocrinology 122:1291-1296

11. Furlanetto RW, Underwood LE, Van Wyk JJ, D’Ercole AJ 1977 Estimation of somatomedin-C levels in normals and patients with pituitary disease by radioimmunoassay. J Clin Invest 60:648-657

12. Copeland KC, Underwood LE, Van Wyk JJ 1980 Induction of immunoreactive somatomedin- $\mathrm{C}$ in human serum by growth hormone: dose response relationships and effect on chromatographic profiles. J Clin Endocrinol Metab 50:690-697

13. Davenport ML, Svoboda ME, Koerber KL, Van Wyk JJ, Clemmons DR Underwood LE 1988 Serum concentrations of insulin-like growth factor II are not changed by short term fasting and refeeding. $J$ Clin Endocrinol Metab 67:1231-1236

14. Maiter D, Fliesen T, Underwood LE, Maes M, Gerard G, Davenport ML Ketelslegers JM 1989 Dietary protein restriction decreases insulin-like growth factor I (IGF-I) independent of insulin and liver growth hormone binding. Endocrinology 124:2604-2611

15. Maes M, Ketelslegers JM, Underwood LE 1983 Low plasma somatomedin-C in streptozotocin-induced diabetes mellitus. Correlation with changes in somatogenic and lactogenic liver binding sites. Diabetes 32:1060-1069

16. Kelly PA, Leblanc G, Dijane J 1979 Estimation of total prolactin-binding sites after in vitro desaturation. Endocrinology 104:1631-1638.

17. Lowry OH, Rosebrough NJ, Farr AL, Randall RJ 1951 Protein measurement with the Folin phenol reagent. J Biol Chem 193:265-275

18. Karsten U, Wollenberger A 1977 Improvements in the ethidium bromide method for direct fluorometric estimation of DNA and RNA in cell and tissue homogenates. Anal Biochem 77:464-470

19. SAS Institute Inc 1985 SAS user's guide: statistics, 5th ed. Cary, NC, pp 956981 
20. Maes M, Amand Y, Underwood LE, Maiter D, Ketelslegers JM 1988 Decreased serum insulin-like growth factor I: response to growth hormone in hypophysectomized rats fed a low protein diet: evidence for a post-receptor defect. Acta Endocrinol (Copenh) 117:320-326

21. Pilistine SJ, Moses AC, Munro HN 1984 Placental lactogen administration reverses the effect of low protein diet on maternal and fetal serum somatomedin levels in the pregnant rat. Proc Natl Acad Sci USA 81:5853-5857

22. Winick M, Fish I, Rosso P 1968 Cellular recovery in rat tissues after a brief period of neonatal malnutrition. Nutrition 95:623-626

23. Winick M, Noble A 1966 Cellular response in rats during malnutrition at various ages. J Nutr 89:300-306

24. Pitts GC 1986 Cellular aspects of growth and catch-up growth in the rat: a reevaluation. Growth 50:419-436

25. D'Ercole AJ, Stiles AD, Underwood LE 1984 Tissue concentrations of somatomedin-C: further evidence for multiple sites of synthesis and paracrine or autocrine mechanisms of action. Proc Natl Acad Sci USA 81:935-939

26. Van Wyk JJ, Trippel SB 1987 Endocrine, paracrine and autocrine effects of the somatomedins/insulin-like growth factors. In: Isaksson O, Binder C, Hall K, Hokfelt B (eds) Growth Hormone-Basic and Clinical Aspects. Elsevier Science Publishers, New York, pp 337-354 